\title{
MATEUSZ STRÓŻYŃSKI
}

Adam Mickiewicz University, Poznań

\section{PSYCHOTIC PHENOMENA IN EURIPIDES’ HERACLES}

\author{
ABSTRACT. Stróżyński Mateusz, Psychotic Phenomena in Euripides’ Heracles.
}

The article is an attempt at the psychoanalytic interpretation of the Euripidean Heracles. The theory used to explain psychological phenomena of the play is Melanie Klein's concepts of the paranoid-schizoid and depressive position, as well as contributions to the understanding of psychotic thinking made by her followers: Hanna Segal, Wilfred Bion, Herbert Rosenfeld, and John Steiner. Characters in the play, in their speech and behaviour, as well as in the chorus' songs, reveal a significant number of primitive psychological mechanisms, such as splitting, denial, idealisation and projective identification. The analysis of those mechanisms expressed in literary material allows to see the much argued continuity of Euripides' extraordinary play.

Keywords: Greek tragedy; Euripides; Heracles; Kleinian psychoanalysis; madness; psychosis.

\section{INTRODUCTION}

The problem of the compositional structure of Euripides' Heracles has drawn the attention of philologists from the outset. Lesky wrote that "it doesn't resemble any other drama in Euripides' canon"1 in terms of content, and Kitto called it "the most enigmatic of Euripides' pieces that have survived." Some researchers have considered the tragedy as a broken composition; however, there is no consensus as to whether it breaks down into two or three separate parts, and where the dividing lines should be drawn. ${ }^{3}$ Other scholars have endeavoured to demonstrate the coherence of the work by referring to its topics or principle

\footnotetext{
${ }^{1}$ Lesky 2006, 425.

${ }^{2}$ Kitto 1997, 220.

${ }^{3}$ Sheppard $(1916,7)$ sees three episodes in the tragedy - from the beginning to verse 814 , since the appearance of Iris and Lyssa (815) until the awakening of Heracles (1087), and from there on to the end (p. 72). Lesky $(2006,435)$ was a proponent of the division into two parts, the second of which is a reversal of the first one. Harsh $(1948,199-200)$, likewise; he also argued that the existing criticism of inconsistency, in fact, clarified little. Murray $(1946,112)$ and Norwood (1964, 46-47), discern two parts, whereas Kitto $(1997,221)$ - three parts. In subsequent studies there prevails a conviction that the composition consists of three parts: Chalk 1962, 7; Kamerbeek 1966, 2; Silk 1985, 2
} 
ideas. ${ }^{4}$ Some works recognize the problem, and suggest that incoherence does not need to determine the tragedy's structural weakness, but it could be the author's intentional, artistic method. ${ }^{5}$ What's interesting, however, seemingly none of the scholars has paid attention to the relation between problematic composition of Heracles and the most conspicuous topic of the tragedy: madness. Perhaps such an interpretation even seems to be too modern, as it would require recognising that the ancient author deliberately made his tragedy on madness incoherent and illogical, thus making the form a certain commentary on the content.

One of the objectives of this article is to prove that both the incoherent structure of Heracles, and a series of illogicalities and discrepancies of other types present in the tragedy's content make up an artistic expression of the principal subject of madness. This method, however, appears to be not so much conscious and intentional, as it results from the impact of the unconscious (in psychoanalytic terms) involved in the creative process. All philologists will surely agree that any author always has some conscious intentions concerning the shape of their work, whereas not necessarily many will agree that what may underlie it are some unconscious motifs which influence this shape with equal force, and to its aesthetic benefit. The latter requires recognising as true (or probable for that matter) the psychological conceptions of the human mind, and acknowledging the benefits of using the analytic method of thinking for the work of the classical philologist.

In the first section of the article, I will demonstrate the methodological assumptions that allow such an application of psychoanalytic methods to interpret drama text. In the second section, I will briefly present a conception of the psychotic phenomena of one of the schools of psychoanalysis, which will provide a theoretical language to understand madness and its expressions in Heracles. In the subsequent section, I will make an analysis of psychotic phenomena in the tragedy until the appearance of Lyssa on the stage. Then, I will enter into discussion with other scholars' views on the psychological coherence in Heracles, and I will suggest an explanation of the dynamics contributing to the climax - the main character's madness. Subsequently, I will make a summary by comparing the discussed dynamics with the second part of the tragedy, and I will suggest a meaning for its radically different nature.

${ }^{4}$ U. von Wilamowitz-Moellendorf (1895, quoted after Chalk 1962,7) - Doric ideal of power

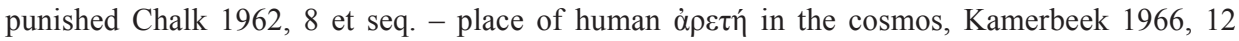
et seq. - Heracles' suppressed anger at Eurystheus bursts out, Willink 1988. 86 et seq. - two meanings of $\pi$ óvos, Silk 1985, 5 et seq. - Heracles' dual divine-human nature, Hamilton 1985: 22 and seq. - a whole array of topics in the debate between Amphitryon and Lycus, Fitzgerald 1991, 92 - Heracles' value system and his identity, Padilla 1992, 1 et seq. - symbolism of the bow and the glance.

${ }^{5}$ Partly - Conacher 1967, 83, and particularly - Arrowsmith 1954, in the work cited by S. A. Barlow, S. A. Barlow herself (1982, 117 et seq.). 


\section{1. "THE ANALYTIC THIRD” AS AN INTERSUBJECTIVE SPACE OF THE DRAMA (METHODOLOGICAL ASSUMPTIONS)}

The psychoanalytic method can be applied to interpret literary works in various manners, each of which may raise other types of doubts, and surely has its limitations. A tool that I'm going to use in this article is the notion of "the analytic third" (or "the third" in short) developed by Thomas Ogden for the purposes of analytic practice. However, this conception, clinical in nature, needs to be adjusted to the needs of literary studies. Ogden writes as follows: "In the analytic situation, as I perceive it, three subjects communicate with one another at an unconscious level: the patient and the analyst as separate subjects, and the intersubjective 'analytic third' (...). The unconscious intersubjective 'analytic third' keeps revealing itself in the emotional field created in the exchange of the unconscious between the patient and the analyst. The third 'subject of the analysis' is one that is created jointly, though asymmetrically, by the analytic pair. The task of the analyst as a separate subject is to recognise and verbally symbolise for themselves (over time) their experiences in the analytic third, and the experiences of the analytic third." "What seems to be useful in this conception for the classical philologist's technique is the existence of essentially metaphorical, divided space which entirely belongs neither to the author of the tragedy, the spectator/reader, nor the work itself. This space resembles the subject in that it can be treated as a kind of mind whose fantasies, defence mechanisms, fears and emotions can be analysed using the psychoanalytic theory.

In psychoanalysis or psychoanalytic psychotherapy, the therapist does not contact with the real person in their entire complexity, but with a certain aspect of the patient who interacts - in a very atypical and specifically determined situation - not with a real-person therapist, but with a certain aspect "the therapist." All the patient does or tells assumes a symbolic meaning, thus expressing what happens in this relationship. When Ogden's patient talks about the way she does the shopping or tries on clothes, this becomes symbolic - apart from the fact that her story's characters are persons and not symbols, the way they behave towards one another expresses the patient's unconscious world of fantasies. Finally, the patient tells in this very moment of her therapy about this specific event, and in a specific manner. This story was being listened to not by, say, the patient's female friend, but her analyst, whose unconscious participated in this process. Ogden writes that once while his patient was talking about her dream, not about real shopping, he recalled helping his friend to buy an engagement ring back in his youth. This recollection allowed him to see something extraordinary in the narration of his patient. ${ }^{7}$ This type of peculiar process can be described using

\footnotetext{
${ }^{6}$ Ogden 2011, 21. Also, compare Ogden 1994.

${ }^{7}$ Ogden 2011, 143-146.
} 
the notion of the analytic third which neither fully belongs to the patient nor the analyst, and which can be overtly filled with the symbolic and bizarre shopping dream, "real" shopping story, and the analyst's memories.

I suggest taking a similar look at Heracles (this may prove valuable for other literary works, too). Euripides the author enters into a certain "dialogue" with an imagined spectator, and creates a tragedy (to make things easier, I will be writing about the "readers"). Drama space becomes the analytic third in which the author expresses his unconscious fantasies together with his conscious ideas, feelings, and everything he is aware of in writing his piece. Euripides fills this metaphorical space both with persons who might be real persons in a similar situation (Megara, Amphitryon, Lycus, Theseus), and persons who are devoid of such "realness" (e.g. the goddesses Iris and Lyssa), as well as chorus songs. The chorus songs and appearance of the gods more resemble a dream told during the session, while actions of persons - a realistic story. One way or another, in choosing and modifying a specific myth or historic setting, taking advantage of a tradition, making literary references, alluding to political events, conveying his own philosophical views, Euripides shares with the reader his own unconscious, which is symbolically expressed in the mentioned conscious content. ${ }^{8}$

Such a methodological approach allows us, as philologists examining the text, to be free enough - in deciding to provide a psychological interpretation - to neither restrict ourselves to an analysis of stage characters treated as realistically presented persons, nor treat them solely as projections of some fantasy. Hence, anything that happens within the space of the drama's analytic third (and the philologist's contribution, both conscious and unconscious, is present here, too) is subject to reflection and analysis, be it the behaviour or statement of a specific character, or the chorus lyrical song, or a motif that keeps recurring in an intriguing way at different moments of the tragedy.

I suggest taking this look at Euripidean Heracles. This method will assume an analysis of the metaphorical space of the work as the "mind" or the "subject", which manifests itself both through statements and behaviour of individualised characters, and literary aspects of the text (style, rhetoric, composition, selection of motifs). If we fully follow this analogy to the analytic third of the therapeutic

\footnotetext{
${ }^{8}$ According to a "biographical model" as referred to by Paweł Dybel (Dybel 2009) which is presently abandoned in the psychoanalytically-oriented Western literary studies, one could seek in the biographical testimonies on Euripides any clues of such identity organisation, in which the psychotic part is highlighted to a considerable extent. Albin Lesky writes: "Euripides was supposedly little sociable, rather taciturn, always engrossed in his thoughts, repulsive. Let us add to this an account from a grotto in Salamis, shown already during the Empire times; the poet looking at the distant sea, far from crowd noise, mused there over the mysteries of human soul. True or not, this picture fits well the image of artist ousted from the life of the community" (Lesky 2006, 316). Although this description corresponds to some features of schizoid, or even paranoid, personality, it would be naive considering it as any material confirming Euripides" "diagnosis."
} 
relationship, then one has to allow for the influence which the work exerts on the reader's sensitivity. This last element appears to go hazardously beyond the "scholarly" framework of the tragedy's philological analysis; however, it can hardly be denied that interpretation of a literary work is to some extent influenced by the scholar's individuality (including the unconscious) determining, among other things, what they observe in the text, how they use their knowledge, and to which elements they react more and which less. ${ }^{9}$

It's worth referring the methods proposed by me to conceptions presented by Norman Holland, one of the most prominent exponents of Anglo-Saxon psychoanalytic literary studies. ${ }^{10}$ Holland emphasises that psychoanalysis is always a method of getting to know the mind, not the text, and that in the case of literature there exist three minds: that of the author, that of the reader, and that of the "person in the text." He perceives the existence of three approaches within psychoanalytic literary criticism: the first one comes from Freud, and is related to the analysis of the author's mind, the second one treats the text as mind, and the third one deals with the reader's mind and the way literary text impacts it. The latter trend represents the method proposed by Holland (reader-response criticism). I would locate this application of Ogden's conception of the "third" for text interpretation closest to the second approach distinguished by Holland (text as mind). However, the approach I propose also includes in the analysis, to some extent, the author's and the reader's minds as subjects co-creating the intersubjective space of the work. ${ }^{11}$

This does not appear to be so much distinct from what analytic therapists do: listening and construing the patient through their human sensitivity; however,

${ }^{9}$ In respect of Heracles, one can see a number of interesting symptoms of such a personal attitude of scholars towards the text. Chalk, for instance, claims that what testifies to Willamowitz's false interpretation is not only strictly scholarly arguments, but also (which he repeats after Parmentier and Ehrenberg) "the predominant impression we derive" (Chalk 1962, 12). Apparently, however, Willamowitz must have gotten a totally different "impression" than Chalk, possessing a similar knowledge and scholarly techniques. Chalk gives Willamowitz's conception a slightly mocking name ("Heracles the Megalomaniac"). Another example is emotional expressions, used to describe Heracles, beginning from "grotesque abortion" by Swinburne, quoted by Verrall (1905) and "broken-backed" by Murray $(1946,112)$. Divergent and emotional reaction of various authors to Heracles will be addressed in the fourth section of this article.

${ }^{10}$ As regards the details of the conception briefly discussed here - compare Holland 1993, 5-21 and Holland 1998, 1203-1211.

${ }^{11}$ Both classic "modernist" approach by Freud (which Dybel calls "biographical model", see note 8), and "postmodernist" approach of Holland himself, based on different reactions that this text evokes in readers in contact with their unconsciousness, appear rather extreme, and in any case, difficult to apply in classical philologist's techniques. The method presented in this article is far from Holland's "structuralist" vision of the text as the mind isolated from the author and the reader; admittedly, it takes into account the author's historic mind and reactions of the modern reader (manly those of the scholar who examines the text), however, what's central for the considerations is the text as a form of crystallising the unconscious mental process. 
they do not confine themselves to this, but transform their experience into the language of theory, before - back to colloquial language - they pass something down to the patient. The classical philologists also read the text construing it as a human being through their intellectual and emotional sensitivity; still though, they do not confine themselves to this, but confront it with their scientific knowledge, and communicate the conclusions as well, albeit in a theoretical language, not a colloquial one. The method applied in this article differs only in that beside the philological knowledge it also uses psychoanalytic knowledge to give meaning to the text.

\section{UNDERSTANDING PSYCHOSIS IN KLEINIANISM}

Among many conceptions of psychosis developed within psychoanalysis, one of the most influential is a theory of Melanie Klein. I will use her views to interpret Heracles, and make occasional references to her most famous disciples: Hanna Segal, Wilfred Bion or Herbert Rosenfeld. In the following section, I will briefly present the most important notions to be used for text analysis. Due to the very brief character of this presentation, interested readers can be referred to the elaborations or source texts of Kleinianism. ${ }^{12}$

Fundamental for this approach to psychosis are the notions of paranoidschizoid position and depressive position introduced by Klein in the 1930s and 1940s. "Position" in Klein's theory means a configuration of feelings, fantasies, fears, and defences against them. In other words, it is an unconscious method of perceiving and experiencing oneself and the world. The paranoid-schizoid position develops during the first months of baby's life as a method of organising its experiences outside the perfectly safe mother's womb. After leaving her womb, in which the baby experienced a condition of instant gratification and general homeostasis, it must struggle for the first time with frustration caused by pain, cold or hunger. From the beginning, the baby is accompanied by the most primitive human fear, which is an annihilating fear, i.e. fear of decay or destruction of the psyche by destructive forces attacking from the inside. Klein claims that the baby experiences the annihilating fear mainly due to a death instinct that's present in it.

The mechanisms occurring already in the paranoid-schizoid position (and later on performing an important function) are projection and introjection. ${ }^{13}$ These are mechanisms-fantasies related to excretion and evacuation or suction

\footnotetext{
${ }^{12}$ Apart from the edition of the writings of Melanie Klein (Klein 2007b), worth mentioning is a classic presentation of Hanna Segal (Segal 2005).

${ }^{13}$ The below sketch of conceptions is based on a classic article: M. Klein, Uwagi na temat niektórych mechanizmów schizoidalnych (1946), In: Klein 2007b, 1-16. References to analytic articles, in accordance with the quoting tradition, are given according to the original text publication.
} 
and swallowing respectively. During the process of introjection, the baby's mind "swallows" a good object and places it in the internal world, where it becomes a source of life and safety. At the same time, the baby introjects the terrifying bad object, and then tries to get rid of it in the process of projection by throwing it out. The baby's first and fundamental object is the mother's breast. However, from the outset it is split into a good breast (gratifying) and bad breast (frustrating). The good breast is used as a source of life, good, love, calm, and safety, while the bad breast is a terrifying cause of evil, suffering, hatred, and destruction. The baby's psychic organ is so weakly developed that its experiences in the paranoid-schizoid position are almost totally dominated by unconscious fantasies which distort reality (e.g. the real quality of motherly care and breastfeeding). Unconscious fantasies are psychic representations of two drives - life (creation, love) and death (destruction, aggression).

Introjection of the good breast is particularly important, as it creates the core of the ego, foundation of safety. It is a seed of subsequent feeling that I exist, I have the right to live, be loved and love. On the other hand, the relationship with the bad breast causes a central fear of the paranoid-schizoid position, which is persecutory fear. The good breast is absorbed in fantasies, and the bad breast is attacked in oral and cannibalistic fantasies of biting, tearing, devouring, etc. The baby separately maintains the good and the bad object, and related feelings by means of the splitting mechanism; therefore in states of gratification love is directed solely to the good gratifying breast, and in states of frustration, it is directed solely to the bad frustrating breast, which reflexively causes persecutory fear (of revenge from the bad breast).

Another mechanism is an omnipotent control, which is the basis of any internal operations at this early stage of development (and later on in individuals suffering from psychological disorders). Idealisation of the object consists in ascribing to the good breast extremely positive features by associating it with fantasies of total gratification. So the idealised breast is then omnipotently resorted to for protection against the persecuting breast. This is accompanied by another mechanism: denial of psychic reality that consists in magical nonrecognition of the existence of the persecutory object and the aggression drive. Finally, thanks to the projective identification mechanism currently considered as one of Klein's key discoveries, the baby places in the object the split, bad parts of itself (the self), thus omnipotently controlling it, and at the same time becomes bound with this object in a strong relationship based on hatred and fear.

To make the processes in question clearer, we can imagine a several-monthold baby which wakes up hungry at night. It experiences hunger as a strong pain which it neither knows nor understands, because its psyche is not mature enough to imagine its mother as a person, and create in itself a feeling that she will soon come and feed it. The baby feels attacked from the inside by something or 
somebody indefinite, and its reaction is fear and rage. The baby experiences this situation in fantasy as a contact with persecutory object(s). In sadistic fantasies, the baby attacks the bad breast by tearing it, crushing it, and violently projecting into it its own aggression together with its urine and faeces. ${ }^{14}$ This projection of aggression into the breast reflexively intensifies the persecutory fear, as now the bad breast filled with aggressive parts of the self turns against the baby in fantasies to take revenge. ${ }^{15}$ Because of the splitting mechanism, the good object, including its related positive emotions, are totally inaccessible to the baby at this moment, so its world turns into hell. Apart from placing in the breast the split parts of the self, and exerting omnipotent control over it, the baby can only make use of hallucinatory gratification, i.e. calling up of the ideal object (accompanied by thumb-sucking).

Usually, after a while appears the mother. If the baby's aggression is not pathologically intensified, it calms down after a while, and the internal image of the object changes from persecutory into good. The baby starts sucking, its hunger vanishes and its internal world changes dramatically. Although objectively, it is being fed by the same breast and the same mother, the baby now has access to the positive part of its relationship with the object, and in its fantasy any evil has been removed from the world by the omnipotent saviour, the ideal breast. The baby has moved in its fantasies from the hell of hatred to the paradise of love. However, when hunger comes back or when the baby has a wet diaper, the previous conditions return.

The other position presented by Klein is the depressive position. It appears with the development of the baby's brain and psyche, when it is able to introject its mother as a whole object, as opposed to the earlier partial objects (breast, face, hands, etc.). Introjection and establishment of the entire good object (mother) inside means appearance of another fear - a depressive one. It is fear of the fact that aggressive attacks which so far have only destroyed the bad breast in fantasy, and which resulted in fear of revenge from it, now are not directed towards the hostile object any more, but towards the loved mother who feeds, loves and cares for the baby. The splitting is getting weaker, while two drives, love and aggression, are approaching each other, just as good and bad aspects of the object and the self. Because in the internal world desire means acting, the baby really destroys its good object in its fantasies. New feelings emerge in it:

\footnotetext{
${ }^{14}$ Kleinians differentiate a healthier mechanism of neurotic projection onto the object, which consists in ascribing to the object the features of the self, from projection into the object, which is generally an identification projection, i.e. placing in the object parts of the self in such a way that the object begins behaving towards the self the same way the self behaves towards the object. In the latter instance, as was later observed, patients provoke the therapist non-verbally to play the role in accordance with the projection.

15 "An innate characteristic of the experience of persecution is the fact that it is simultaneously reinforced by hatred, and itself reinforces hatred." (Klein 1940, 354, 363).
} 
pain of loss, deep sorrow, and a feeling of guilt due to its own aggressiveness. The baby is experiencing its first grief.

Klein argued that if in the baby's internal world death drive predominates over life drive, and there is more hatred than love, then the persecutory fear still prevails, and the depressive position experiences become unbearable. The coming together of good and evil terrifies; therefore, the baby intensifies splitting instead of ignoring it. The baby can then perform regression to the earlier paranoid-schizoid position, protecting itself from experiencing grief and guilt. This is exactly a paradox of psychosis, where the fear of destruction of the self by the bad object is easier to bear than the pain of the self due to the fact that it has destroyed the good object. Breaking up with reality in favour of illusion which seems to prevent suffering impoverishes the psyche, and causes destructive disease. This painful paradox is rendered by a statement of Wilfred Bion, sometimes quoted, addressed to one of his patients: "It's a pity you have restricted yourself to omnipotence."16

Such a failure in working out the depressive position according to Klein leads to psychotic disorders of various types and degrees of intensification. Working it out means first of all admitting feelings of pain, sadness and guilt, and then undertaking a so-called reparation, i.e. activity (also taking place in fantasy, but represented in the child's play) of "repairing", i.e. reproducing and rebuilding the object destroyed in fantasy, and making up for its own aggressive impulses. The ability of object reparation is a source of subsequent creative abilities and the skill of loving. Working out the depressive situation also enables a process of symbol creation and symbolic thinking, as well as a more objective perception of reality. The baby perceives the mother in a more real and multidimensional manner (just like itself), differentiates between the world of fantasy and the real world, and establishes in itself a lasting good object that gives it a feeling of safety.

Hanna Segal and Wilfred Bion focused on differences between psychotic and non-psychotic "thinking." Segal claimed that the ability of using the symbol in the full meaning of the word requires an ability to tell the self from the object, external reality as distinct from internal reality, as only then does there exist a sense that the symbol and what's symbolised (this originally being the object) are both different from each other and related with each other. What resembles the symbols in the thinking of persons with psychological disorders whom Segal worked with, was called by her, by contrast, "symbolic equation." This means that a psychotic person gives the impression that they use words and symbols in communication, while in reality the words and symbols they use do not mean things - they are things. An example often brought up by Segal refers to one of her patients who used to be a violinist before he came down with schizophrenia.

\footnotetext{
${ }^{16}$ Quoted after Ogden 2010, 106.
} 
When the doctor asked him why he had stopped playing since he had become ill, he replied abruptly: "Why? Do you expect me to masturbate in public?"17

\section{PARANOID-SCHIZOID PROCESSES IN HERACLES}

The first part of Heracles is dominated by processes characteristic of the paranoid-schizoid position. In the prologue, there is a very clear persecutory image of Lycus. Heracles' father - like Megara and Heracles himself - perceive Lycus in a totally bad manner; he has no positive feature. We know from allusions that Amphitryon himself has destructive impulses because he killed his failed father-in-law, Alcmene's father, and justifies twice the infanticide committed for political reasons (39-40 and 206-7), in a similar manner to that of Lycus (165-9). ${ }^{18}$ In Amphitryon's relationship with Lycus and that with his internal image, one can see an instance of the projective identification mechanism and its related paranoid vicious circle. Amphitryon is in a situation of total helplessness and weakness, he tries to control the object omnipotently by placing in it his own split bad parts. However, the bigger Amphitryon's hatred (self) to Lycus (object), the more the image of Lycus becomes hostile, and the greater fear it raises in Amphitryon. Still, Amphitryon, getting rid of his own aggression, experiences himself as helpless. Euripides conveys the projective identification by means of

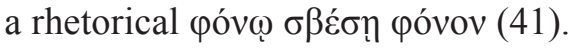

At the same time, in response to the persecutory fear there appears an omnipotent reference to the ideal object. Klein writes: "States of frustration or fear force the baby to flee from its persecutors into its internal, idealised object." 19 It's Zeus, with a telling nickname "the saviour", who becomes this object ( $\sigma \omega \tau \eta \dot{ } \rho$ 48). The altar of Zeus, at which Amphitryon took shelter, apparently merges with the ideal object in his experience, thus making up a "symbolic equation." This sitting at the altar is supposed to ensure Amphitryon protection from the persecutory object, which later on turns out to be ineffective. Amphitryon also combines in this symbol not only Zeus, but also Heracles, who had built the altar, which is another example of magical thinking (48-50). Amphitryon feels as if he were drawing on the power of the object by sitting at the altar.

Whereas the combination Lycus/Zeus-Heracles represents the mechanism of splitting the object into ideal/persecutory, the dialogue of Amphitryon and Megara expresses a complementary splitting of the self. ${ }^{20}$ Megara symbolises

\footnotetext{
${ }^{17}$ This conception and the example come from: Segal 2006, 78.

${ }^{18}$ Compare, Chalk 1962, 17.

${ }^{19}$ Klein 1946, 10.

20 "The baby splits the object and the self in fantasy, but the result of this fantasy is very real, as what it leads to is that feelings and emotions (and subsequently thinking processes) get cut away from one another." (Klein 1946, 7).
} 
here a weak, depressed aspect of the self, which has totally abandoned the hope (85-106), persecuted by ominous Lycus. Amphitryon represents the self, which tries to identify itself with the ideal object (Zeus - altar - Heracles). Megara can't stand the waiting for rescue. What's interesting, Megara says earlier that in telling stories she tries to divert the children's attention away from their father's absence, and Amphitryon tells her to continue doing this. One could wonder whether Megara's activity (which appears to be strictly intertwined with what she experiences together with Amphitryon) is dominated by the psychotic part of her personality, or represents a more mature form of her thinking. True symbolic thinking means evoking the presence of mother (based on the internal good object) by a symbol - image, word or thing, which substitute for her. Bion describes this process as the appearance of thoughts out of a painful void of the "missing breast." However, if thinking is not developing, instead, we do not have a symbol, but hallucination, ideal object, magical thinking, which protect from an attack of the bad object. ${ }^{21}$

The general mood of the scene in question inclines one to preferably admit that both Megara and Amphitryon rely on denial, splitting, etc., rather than more mature thinking. Megara herself is unable to evoke in herself any support, and what's more, she attributes all her longing to her children and Amphitryon by means of projective identification. She sees in her children her longing, which hurts her; therefore she lies to them by saying something she doesn't believe herself. Amphitryon has his own "hope" based on his retreating into his omnipotent fantasies, but he is scared by watching Magara's and the children's despair, so he talks her into calming them down by lying. These aspects are emphasised by Euripides through repetitions of $\kappa \lambda \varepsilon \dot{\pi} \pi \varepsilon \varepsilon v$ and $\kappa \lambda \circ \pi \eta$ in Amphitryon's utterance (99-100).

In the first epeisodion, Lycus finally appears on the stage, about whom we have only just heard. Lycus derisively attacks Zeus and Heracles, who are the only point of reference for Amphitryon, by undermining the value of his labours, and suggesting that he had completed them not using his power or mind, but deception (151-155). Amphitryon undertakes to defend Heracles, and in the agon of the two characters a schizoid oscillation between omnipotent referencing the ideal object (Heracles as invincible victor), and equally hostile devaluation of his character as a crook and false hero reveals itself.

In these agons, first between Megara and Amphitryon, and later on between Amphitryon and Lycus, we are dealing with two perspectives at a time. In individual utterances of each character can be found psychotic features, some sort of loss of contact with reality in favour of fantasy. However, when we see them all at the same time in a metaphorical space of the drama, in the combining them by Euripides, the clarity of splitting and denial mechanisms reveals itself.

\footnotetext{
${ }^{21}$ Bion 2010, 74-75.
} 
The characters do not experience both the positive and negative features of any person. Heracles is either an ideal saviour or a crook, Lycus is a monster, Megara is solitary and resigned, and Amphitryon naively believes in rescue. Each of these persons demonstrates another part of the shattered psyche - the object or the self. ${ }^{22}$

Another aspect of splitting, this time notable not on the stage, but in the utterance of one of the characters, is the devaluation of Zeus made by Amphitryon, when no rescue comes. Amphitryon takes away Zeus' attributes, which he earlier has ascribed to him (1-2 and 48-50), taking pride in that he

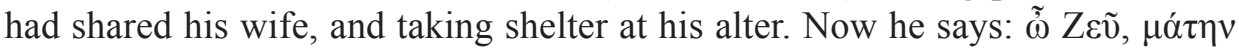

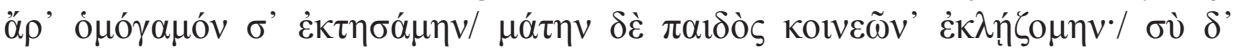

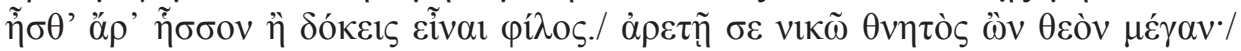

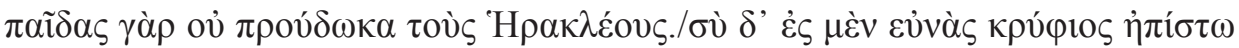

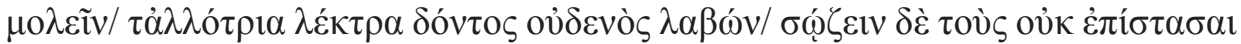

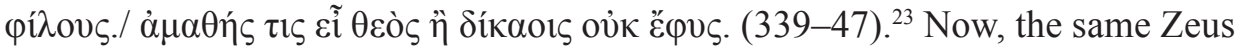
is experienced by Amphitryon in an extremely different way - as treacherous, greedy, one who by abuse and with no permission had appropriated someone else's wife, and finally, also helpless, stupid or unjust.

Here, for the first time in tragedy appears a phenomenon which Klein developed towards the end of her life, calling it greed and envy. "Envy is a sense of anger at the fact that somebody else has and enjoys having something desirable, and gives an impulse to take it away or damage [it]" - writes Klein, and "greed is a violent and insatiable endeavour exceeding what the subject needs, and what the object can, and is ready to give. (...) Envy aims not only at robbing in this way, its objective is also to place bad things, mainly bad faeces, and bad parts of oneself in the mother, and primarily in her breast to damage it or destroy it in this way." ${ }^{25}$ The situation of a lack of the sense of safety, love and good intensifies greed and persecutory fear, and stimulates fantasy of the inexhaustible breast which has everything that the subject desires the most, yet refuses to give it to the subject, withholding the love and the good for itself. This

${ }^{22}$ Hamilton $(1985,20)$ specifically analyses the devaluation made by Lycus, but also demonstrates how Megara and Amphitryon artificially raise their self-esteem ("their exaggerated sense of self-worth") based on their relationship with Heracles.

23 "Zeus, it does no good that you were my wife's lover, no good that I have called you sharer in my son's begetting. You were, it now appears, not as near a friend as I thought. In goodness I, though mortal, surpass you, a mighty god. I have not abandoned the children of Heracles. But you, though you know well enough how to slip secretly into bed and take other men's wives when no one has given you permission, do not know how to save the lives of your nearest and dearest. Either you are a fool of a god or there is no justice in your nature." Text according to Teubner's edition (Lepizig, 1988), translation from Kovacs's Loeb edition (Cambridge - London, 1998).

${ }^{24}$ Klein $1957,185-245$ in Klein 2007 b

${ }^{25}$ Klein 1957, 190. 
arouses envy, i.e. a desire to rob the ideal breast of its riches, and to aggressively fill it with toxic faeces (bad parts of the self).

This corresponds exactly to what Amphitryon does with relation to Zeus. First, his persecutory fear of Lycus grows, and the prolonging abandonment turns into despair. Amphitryon experiences the same condition which earlier was displayed by Megara - hopelessness, resignation and despair, which

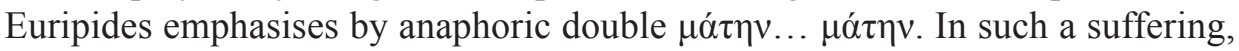
Amphitryon stops searching for care in the ideal object, and what awakes in him is a hidden-under-idealisation envy of happiness, power and love, which Zeus has, and which he keeps to himself without helping him.

Therefore, in his fantasy Amphitryon robs Zeus of some of his attributes (virtue, fairness, and wisdom), and projects into Zeus his own weak, helpless and bad parts (symbolic toxic faeces), which results in Amphitryon experiencing himself as more virtuous and wiser than Zeus. The ideal breast is "damaged", filled with split psychic "faeces", which unfortunately does not improve his situation. Apart from the fact that Amphitryon triumphs in his fantasy over the object ( $\sigma \varepsilon v i \kappa \tilde{\omega} \theta v \eta \tau \grave{s} \varsigma \hat{\omega} v$ ), in reality, he destroys the source of good and love by his aggressive projective identification.

It seems intentional that just after such devaluation of a divine saviour Zeus, the chorus in the first stasimon introduces an idealised character of a human saviour - Heracles, extolling his twelve labours. Zeus stops fulfilling the function of the ideal object in the space of the drama, and the rising fear of Lycus requires defence in the form of idealisation and denial. That's why the chorus omnipotently establishes another ideal object - Heracles in lieu of devaluated Zeus.

The chorus in tragedy is particularly an exponent of unconscious space of the drama. The language of chorus songs and the method of imaging is strongly affected by psychotic features. Chorus songs represent dream in tragedy (or rather, according to Bion's theory, "night hallucinations", because a psychotic person is not able to dream in a symbolic manner), in contrast to a more realistic interaction between characters, which corresponds to being awake. This specific quality of dream/hallucinations of chorus songs is only announced in the parodos,

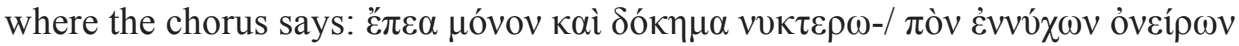
(111-112). The chorus is fit for such a role also because it is a collective entity as opposed both to the characters, and e.g. the Messenger who carries out his observations from a more objective position.

As regards the first stasimon addressed here, Shirley Barlow brilliantly analyses the unrealistic language, in which there is an astonishing avoidance of phraseology which might have aggressive and brutal connotations during the description of Heracles' labours. In total contrast to the style and imaging of the chorus stands the Messenger's description, brutal in its precision. Barlow demonstrates that Euripides begins with fantasy, gradually moving towards 
reality. ${ }^{26}$ What the author calls "planes of reality", at the psychological level refers on the one hand to the world of omnipotent fantasies, and on the other hand to the real word. The chorus is here an extreme representative of the first world, with one exception - the hallucinatory and delusional episode of Heracles.

Beside the unrealistic tone of the chorus songs, its important feature is avoiding brutality. It results from the fact that the labours extolled by the chorus are manifestations of the ideal object, split and omnipotently established for protection from persecutory fear. The chorus represents here a mechanism which Klein (after Freud) calls hallucinatory gratification. She writes: "The main processes present in idealisation, namely splitting of the object and denial of both frustration and persecution, also act in hallucinatory gratification. The ego not only keeps the hallucinatory and persecutory object away from the idealised object, but goes further by denying its existence just like the entire situation of frustration and bad feelings (pain), which result from it. (...) Denial of psychic reality is only possible due to a strong sense of omnipotence which is an essential feature of early mentality (...). Therefore, in hallucinatory gratification take place two mutually related processes: omnipotent establishment of the ideal object, and equally omnipotent annihilation of both the bad persecutory object and the painful situation." ${ }^{27}$

The chorus song makes evident these primitive psychic phenomena step by step. The chorus begins with a mood of despair, saying that it should sing a'i $\lambda$ ivov after Heracles' death (348), it totally ignores the fear of death from Lycus growing on stage, and states that instead it wants to extol Heracles' labours ( $\theta \dot{\varepsilon} \lambda \omega 356)$. This way, the chorus keeps the persecutory object away from the idealised one - Lycus and the deadly threat disappear from the stage, and the readers are invited to immerse themselves in the chorus' hallucinatory images. The chorus denies the existence of evil by omnipotent annihilation of the bad objects made symbolically by Heracles, who subjugates or kills monsters. In the sons dominates a sense of the main character's omnipotence and his ideal nature - in principle, he is not a human being, but god. ${ }^{28}$ Barlow also points out

26 "Each mode represents a different plane of reality: one remote, romantic, decorative (adjectivally oriented), the other close, grimly unsentimental, ugly (verbally oriented)." (Barlow 1982, 121).

${ }^{27}$ Klein 1946, 7-8.

${ }^{28}$ Barlow $(1982,117)$ writes: "The absence of Heracles is not merely the absence of an ordinary man but of an almost superhuman hero of whom miracles in the past have been expected." The mood of the stasimon does not escape the attention of Sheppard, who sees in it a combination of two characters: Lycus and Heracles, as well as the fact that Heracles appears to be a god, in which the author senses an unclear threat. What's interesting is that Sheppard immediately backs down on the observation of Heracles' "superhuman greatness", and states that we must "ignore the lyrics", because after all Heracles must be a fully human character, and not idealised and irregular (Barlow 1982, 76-78). Chalk $(1962,17)$ perceives in the first part a generally "melodramatic" combination of utterly differently seen good and evil, but only tries to explain it towards the end 
that the song is generally made up of loosely related images which have neither logical nor temporal order. This appears to be the third of the psychotic aspects of this stasimon. ${ }^{29}$

It's worth saying more about the symbolism of Hades, to which Heracles is said to irrevocably have gone (427-429), and who appears at the end of the song. Hades may mean a world of inner fantasies as opposed to the sunny, real world of the earth, similar to the human-divine opposition. Heracles' descent to Hades can thus be interpreted as a psychotic breaking up with reality and immersion in the world of omnipotent fantasies (which, in parallel, to a lesser extent is shared by Amphitryon and Megara, and undoubtedly the chorus). It is also a portent of subsequent madness which will afflict Heracles himself.

What's interesting is that the scholars do not comment at all on the symbolism of Hades in discussing this stasimon. However, what doesn't escape their attention is a more visible compositional technique of Euripides, who in Heracles astonishingly reverses the generally accepted mythic sequence of events (first madness, then the labours as atonement). A similar sequence modification is present in the chorus song - irrevocable entrance into Hades after completion of the labours may symbolise immersion in madness and turning of the whole good into ruin. At the end of the song returns the negative mood of the first verses, only deeper. In the chorus utterances appear images related to emptiness and

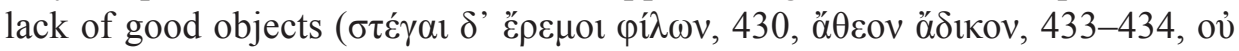
$\pi \alpha \rho o ́ v \tau o \varsigma$ 435).

In the second epeisodion, this mood of impending decay and disintegration of the psyche is continued as a result of attacks of the bad object. In this extreme situation appears an interesting trading of roles between Megara and Amphitryon. Megara, who had been devoid of hope, now calls on Heracles to save them (490-496). Now, it's she and not Amphitryon who omnipotently establishes the ideal object, which is to protect the self from persecutions and destruction. Her words echo the chorus song as there appear in them elements of hallucinatory gratification as well. Megara calls on Heracles to - metaphorically - brighten

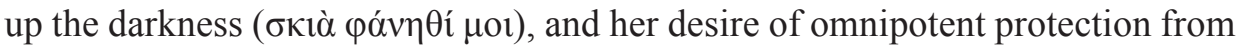

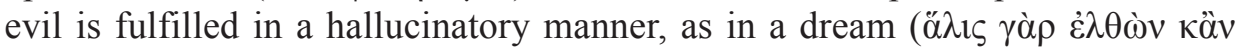

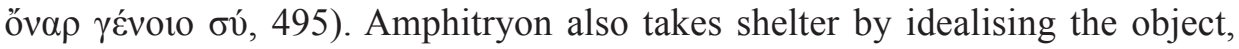
and, what's interesting, he calls for help once again from the idealised figure of Zeus (498-500), although previously it had been the object of his envious attack. This, however, doesn't produce the expected results, and after a while

of his article, after complicated analyses of the third part, as Euripides' warning against excessive focusing on what's good, as this can lead to overlooking irrational forces. Silk claims that Heracles is a character suspended between the sphere of the gods and that of human beings, he is neither fully divine nor fully human. However, in the case of the chorus song in question: "god-heroic aspect was amplified" (Silk 1985, 13).

29 “Time does not matter. Order does not matter." (Barlow 1982, 118). 
Amphitryon returns to the attitude of the abandoned and weak self, which earlier

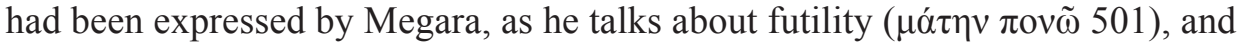
falls into despair.

Then, Heracles appears on the stage. Although this is a moment in which he "materialises" on the stage in a way, his realness to some extent remains as if a dreamy one. It is suggested by the language used in the beginning by

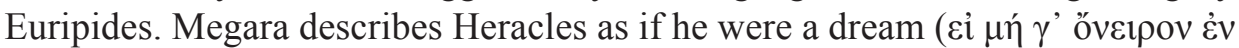

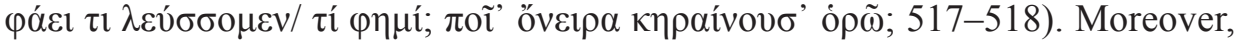
she equals him omnipotently with Zeus, the saviour (521-522). On the stage appears not so much Heracles - the real man, but Heracles - the ideal hero from the previous chorus fantasies. Euripides again trades the roles of Amphitrion and

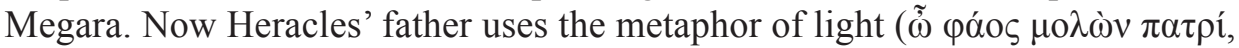
531), and Megara emphasises once again the divine attribute of the saviour

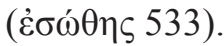

Heracles identifies himself with Amphitryon's and Megara's omnipotent idealisations by delivering a euphoric speech, in which he himself sees himself as a powerful saviour who is able to destroy persecutory objects, and protect both the good objects and the self (first of all, his own children, but also his wife and father: 562-282). Heracles' utterance is a catalogue of sadistic fantasies, oral, anal, urethral and phallic in character. ${ }^{30}$ There appear images of destroying a palace (tearing the breast apart), beheading (biting off the nipple), throwing to the dogs (oral biting and devouring), crushing with a club (the aggressive phallus), piercing with arrows (anal faecal "bullets"), and poisoning a river with blood (poisoning the bad breast with toxic urine).

By surrendering to these fantasies, Heracles is not in contact with reality, and Amphytryon is trying to restore this contact (588-594). His son experiences sadistic attacks on the bad object, which reflexively intensify persecutory fear. If Heracles attacked Lycus according to his impulsive plan, he would get killed by Lycus's supporters that were numerous in the city (the bad object undergoes fragmentation, and attacks in the form of a whole mass of enemies, "bizarre objects", as Bion called them, containing split parts of the broken self"). This moment is another portent of Heracles' madness, who - though coming back from Hades - is still symbolically imprisoned in it to some extent. ${ }^{31}$

${ }^{30}$ Oral sadism means fantasies relating to sucking out, biting off, tearing apart, emptying, and robbing the mother's breast/body. Anal and urethral means throwing away with faeces/urine of the bad parts of the self and their related aggression, which faeces are supposed to damage the object or take possession of it. Fantasies of bad split phallus appear, according to Klein, as early as in the paranoid-schizoid position, where there is still no realistic relationship with the father as an overall object.

${ }^{31}$ The scene in question was for Willamowitz, Murray, Dodds and Grube a basis for discerning earlier signs of madness in Heracles (see Chalk 1962, 8-9). Verrall $(1905,156)$ here describes Heracles as "verging on delirium." . According to Burnett $(1971,165)$ Heracles speech is 
The second stasimon (655-672), like the previous one, makes up a series of loosely related images ("Time does not matter. Order does not matter." 32 ), and reflects the unconscious psychotic process taking place in the drama space. ${ }^{33}$ The chorus again begins with the sense of persecution, the bad object being old age whose burden resembles Etna rocks in fantasies, crushing down on the head and covering up the eyes with darkness (incidentally, what's interesting is the implication of these metaphors as they seemingly correspond to likely fear of the baby in contact with the breast that crushes down on the baby). Then, the chorus sadistically fantasises about attacks on the "murderous" object ( $\lambda v \gamma \rho$ òv

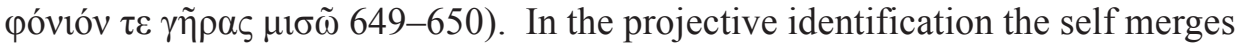
with the object so that both old age destroys the chorus and the chorus destroys old age, which is emphasised by one expression matching both parties of the relationship ( $\varphi$ óvıv). The chorus destroys the object my drowning it in waves,

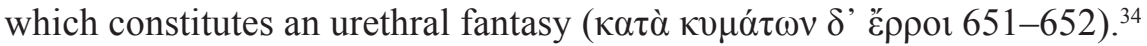

Then, in an attempt to protect from the growing sense of persecution resulting from the projective identification, the chorus omnipotently denies the existence of time and human- condition limitations. The idealised self, full of virtues, will be revived and young, like the idealised Heracles who returned from the land of death. ${ }^{35}$ This idealisation of the self is not only related to the desire to protect oneself from the bad object, but also with envy at the good object. The chorus, unable to tolerate the power and happiness of the gods, tries to enviously rob and devalue them. It suggests that they are not fair and wise enough since they do not grant double youth to virtuous people (655-658). What operates here is a primitive envy through which the chorus wants to suck out from the gods their

\footnotetext{
"unusually indiscriminate in its ferocity". Silk $(1985,12-13)$ proves that both the psychological posture, and the language used resemble a typical god's speech in tragedies and epics, though he does not regard it as a hint of coming madness. Lesky $(2006,429)$, in the support given by the chorus leader to Heracles' "wild speech" sees an argument against Heracles' growing madness.

${ }^{32}$ See note 27.

${ }^{33}$ Parry $(1965,363-364)$ writes that many scholars emphasise the incoherence of this song. For instance, it is unclear whether the chorus expresses itself in it as a group of elders or as Euripides himself. Parry sees a considerable incoherence here that is based on a method of passing from the general to the particular, and formal resemblance to Pindar's epinics.

${ }^{34}$ Lesky $(2006,429)$ points out here that it is an imitation of a cult form apopompe, i.e. magic ritual of getting rid of bad things, e.g. by drowning them. Of course, it is difficult to consider a cult ritual as a symptom of psychosis, as psychosis is a rejection of culture and its "symbolic order", but in primitive cultures can be seen mechanisms which appear in the paranoid-schizoid position, and which in adult persons of the Western culture would point to psychotic features. In this case, this mechanism means using the symbolic equation and mass projective identification.

${ }^{35}$ This idealising aspect is pointed out by Parry $(1965,364)$. The formal aspects of the song testify to that it is virtually a hymn to a god, and not to a human being. Pindar emphasises in the epinics that the character is not a god; here, this aspect is not present at all, and Heracles appears here precisely as a god: "the chorus elevate their hero to so dangerous a height that his fall becomes almost inevitable.". This is also perceived by Silk $(1985,13)$.
} 
eternal youth and freedom from death, their fairness and wisdom, and after the envious robbery from the ideal breast, the breast is filled with aggressive and bad aspects of the self. This allows the chorus - like earlier Amphitryon - to feel better than the gods, all the more so as in lieu of them it has found another ideal object - Heracles, whom it omnipotently establishes as a guardian.

It's also visible that the fear of the chorus also concerns the fact that there is no clear border between good and evil (by fault of the gods), and it would be conspicuous should the virtuous be granted another youth. There appears an image of sailors who cannot reach the stars because of the clouds. The chorus is afraid of the mutual approaching of love and aggression, and that of the good and the bad object (for fear of destruction of good by evil), with which it copes by intensification of the splitting. ${ }^{36}$ The second verse is again filled with a hymn to Heracles. ${ }^{37}$ In the antiverse, the chorus affirms that it will sing a paean for Apollo, such as for Heracles, which constitutes an idealising equation of the hero with the god. At the end of the song, the chorus exclaims that Heracles gave

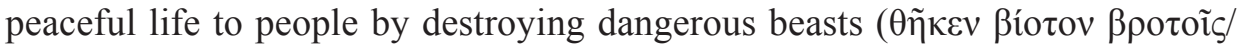

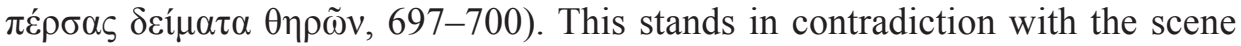
in which Heracles kills Lycus - bad, but after all, human, and announces an impending catastrophe.

An almost idyllic mood of this chorus song contrasts with the mood of the next song, full of sadism. In the first antiverse, the chorus takes delight in the suffering and death of Lycus, just as Amphitryon had done this earlier, and

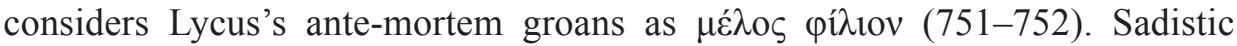
$\mu \varepsilon \dot{\lambda} \mathrm{o} \varsigma$ of the chorus again reveals the splitting in relation to the ending of the previous song, primarily, because back there brutality and evil were magically removed from the world, and here the chorus rejoices in violence, secondly, back there the chorus enviously denigrated the gods, and here it announces that Lycus died fairly because he had claimed that gods had no power. These two aspects, aggression and envy, are continually split, denied, and then projected by both Amphitryon and the chorus.

In the second antiverse, the chorus enters into an utterly different configuration of relationships with the object, because it omnipotently restores the function of ideal objects to the gods, seeing no discrepancy whatsoever in that not long ago it criticised them for not demonstrating the difference between good and evil.

${ }^{36}$ Parry $(1965,368)$ claims that it is simply a desire of the chorus to obtain a clear response on who is virtuous and who is not.

${ }^{37}$ This, according to Parry $(1965,372)$, is a solution to the central problem of this stasimon, that is - how to distinguish virtue from wickedness. The chorus affirms here that only Muses and Charities (poetic inspiration and beauty of the form) can demonstrate this difference by praising the virtue: "there remains one outstanding means whereby à $\rho \varepsilon \tau$ ' may be revealed, and that is through the power of song." 
Now, it extols them for punishing evil and rewarding piety (773-780). ${ }^{38}$ In the third verse, the chorus again euphorically enjoys the world from which evil was magically removed, and then it invokes the earlier image of idealised divinehuman marriage which gave birth to Heracles. Here are revealed early fantasies related to the pair of parents described by Klein. The marriage, in which a god and a human being share the bed with the same woman, constitutes a symbolic source of life by giving birth to a powerful saviour. The image is inadequately idealised, because what's removed from it are any negative aspects, which after all appear both in the earlier accusation of Amphitrion, and in subsequent recognition of this marriage as a source of all misfortunes (as it had aroused Hera's hatred towards Heracles: 1307-1309). The image of a marital bed which produced Heracles is subject to several omnipotent operations in the play. In moments of "frustration" it is experienced as perverse, treacherous and sadistic, and in moments of "gratification" it is sacred and giving birth to power. In addition, logic and relation with reality are denied, e.g. by the fact that Heracles after all cannot come from the semen of two males or that a love triangle (or in this case quadrangle) cannot be perceived by all those concerned as a good situation. ${ }^{39}$

The first part of the tragedy, acknowledged by the scholars as melodramatic and difficult to associate with what follows, from the psychoanalytic perspective turns out to be a description of a psychotic process taking place in the analytic third of the drama, with fantasies, fears and defensive mechanisms characteristic of the paranoid-schizoid position. However, we do not observe an overt or acute psychosis, either in any characters or in the general organisation of the literary material. What happens preferably corresponds to processes occurring in a person endangered by psychosis, but who - for the time being - is coping with the unconscious fear by massive application of defensive mechanisms. The unrealistic nature and bizarreness of this part is seemingly integrally related with madness, being its portent and, partially, expression, and the description of Heracles' madness that follows is hard to consider as something that appears unexpectedly and afflicts the totally sane Heracles.

\section{PROBLEM OF PSYCHOLOGICAL CONTINUITY IN HERACLES}

Although psychotic mechanisms are clearly present as early as in the first part of the tragedy, in the second part, they manifest themselves in a violent

\footnotetext{
${ }^{38} \mathrm{Harsh}(1948,202)$ perceives in it a tragic irony.

${ }^{39}$ This "dual parentage" is addressed in an article by J. D. Mikalson (1986), but although he describes these changing perceptions of the bed which produced Heracles, he fails to explain them in any way whatsoever.
} 
hallucinatory and delusional episode of Heracles. From the psychoanalytic perspective it does not constitute anything completely unexpected or coming totally from the outside, but is a culmination of the process growing previously. However, this is not the process referred to in Willamowitz's conception so strongly opposed. ${ }^{40}$ The view on Heracles' madness (but without him to blame) was also expressed by Pohlenz and Verrall. ${ }^{41}$

Another psychological approach was applied by Kamerbeek, who formulated several cautious hypotheses to relate Heracles' madness with the earlier parts of the tragedy, and his past in general. An argument in favour of such relations is for Kamerbeek the already mentioned Euripides' method consisting in intentional reversal of the labours-madness relation contrary to the known literary and mythic tradition. Kamerbeek's hypotheses are the following:42 (1) Heracles' madness begins before Lyssa appears on the stage, (2) Heracles' madness can be a violent reaction to the futility of the labours which had not contributed to ensuring safety to Heracles' family, or it can result from his being overwhelmed by life's hardships, and (3) the content of the hallucinations and delusions relates the madness with Heracles' service with Eurystheus - the hero was angry at the king of Mycenae for putting his family at deadly risk, however he suppressed his desire to take revenge for rational reasons. When rational control broke down, the suppressed anger overtook Heracles and led him to madness. Kamerbeek perceives Heracles' unclear utterance from the third part of the tragedy (13861388) as a request for Theseus to guard him, as he himself was afraid that he would not control his anger at Eurystheus. ${ }^{43}$

In the psychoanalytic context, all Kamerback's arguments can be accepted, except the last one. Indeed, as I suggested earlier, reversal of the labours-madness relation as well as the symbolism of descent to Hades testify to the existence of certain "susceptibility to madness" in Heracles. Undoubtedly, a factor triggering acute psychosis could have been the sense of being overwhelmed by life's hardships, and his awareness that combating evil in the world had not contributed to protecting his own family from it. Also, it seems to be clear that Eurystheus does not appear in Heracles' persecutory delusions by chance. Psychoanalysis claims that disorders are always "overdetermined", that is, they have multiple

${ }^{40}$ This German philologist argued that Heracles represents here a Doric ideal of male power ( $\left.\beta{ }^{\prime} \alpha\right)$ that is accompanied by $\ddot{\beta} \beta \rho 1 \varsigma$, for which he is punished by the gods. In the last part of the tragedy, the character undergoes transformation and becomes passive by abandoning the way of violence (Wilamowitz, quoted after Chalk 1962, 7 et seq.).

${ }^{41}$ Kamerbeek $(1966,10)$ argues with the unjustified, in his opinion, use by Pohlenz of ancient testimonies, e.g. by Aristotle (Prob. 30.1), who gives Heracles as an example of a melancholic type.

${ }^{42}$ Kamerbeek 1966, 12-13.

43 "[requests of] Theseus' help in setting the reward for carrying the Cerberus to Eurystheus" (Kamerbeek 1966, 15-16). 
causes, therefore Kamerbeek accurately describes various aspects that could have contributed to psychotic decompensation. Kamerbeek's suggestions (those mainly concerning external conditions and conscious experiences of the hero) can be treated as a complement to the unconscious factors (relations to the objects, primitive defences, etc.) analysed here.

It's difficult, however, to agree with Kamerbeek's last idea that to some extent makes reference to popular psychology (influences of Freudianism are visible here, too). What this scholar has in mind here is a mechanism in which suppressed or impulsive content bursts into the consciousness as the repression breaks down. For this to happen, there must exist a barrier between the ego and the id, whose existence was discovered by Freud and other analysts in examining neuroses. Nevertheless, the analysis of patient with deep disorders (psychotic and borderline) led to a conclusion that separation of psychic structures and establishing a repression barrier is a developmental achievement of the oedipal period (3-7 years of age) and it does not exist in psychotics or persons with deep personality disorders.

The neurotic is generally in good contact with reality (the depressive position worked out - as put by Kleinianism), and aggressive and sexual impulses are maintained by them outside their consciousness by repression, rationalisation, and other mature defence mechanisms. The psychotic, in turn, does not apply repression to get rid of aggression, etc. Hence, the primitive defence mechanisms discussed here, like splitting aggression from love, evacuating it through the projective identification, denial, etc. In the first part of Heracles, we do not observe the neurotic attitude towards aggression at all - neither Heracles nor other characters (nor the analytic third of the drama) attempt to repress aggressive content, rationalise it, or substitute love for it by means of reaction formation, which would be a neurotic strategy. Aggression, however, is ubiquitous in fantasies and actions, be it Heracles' sadistic fantasies or his murder of Lycus, and is attributed to other persons. What we are dealing with here is a breakdown of defences, but not neurotic ones. A Kleinist hypothetical understanding of the causes of this breakdown will be presented later on.

Studies published in the 1960s and 1970s marked a trend focused on proving that Heracles' madness has neither any relation with his past nor his inner psychic life, but is a symptom of irrational interference of the gods. Chalk, ${ }^{44}$ one of the main proponents of this thesis, makes reference both to Euripides' views that he discerns in the tragedy, and the utterances of the characters. According to Chalk, Euripides sketches an image of immoral gods, as being virtuous is only characteristic of human beings. Apart from presenting the conception of two types of virtue in Heracles ("active achievement" and "impotent endurance"45),

\footnotetext{
${ }^{44}$ Chalk 1962, 15-17.

${ }^{45}$ Chalk 1962, 12.
} 
Chalk claims that the tragedy demonstrates that violence ( $\beta i ́ \alpha)$ exists both in the human and divine world, and is unavoidable.

A similar view was presented half a century later by Karelisa Hartigan, and her views appear to be even more poignant and radical. She compares Heracles to Oedipus, and puts emphasis on his being totally "innocent", as if Willamowitz and other scholars up until Grube had tried to accuse Heracles of anything." ${ }^{46}$ Hartigan wants to see a good man in the hero crushed by an unexplained irrational fate. She fleetingly notices the relation between Heracles' labours (proof of his goodness) and his murder of Eurystheus in madness (a sign of his violence and folly) by calling the latter another labour of the hero. ${ }^{47}$ At the same time, however, she ignores those relations by concluding that there is not any continuity between the "sane" and the "mad" Heracles. In addition, she builds her opinion on a strong contrast between his good character and the bad gods. ${ }^{48} \mathrm{~A}$ similar picture of Heracles can be found in an article published one year earlier by Mikalson, who states that Heracles' piety is extraordinary, and that - although in Euripides' tragedies misfortune usually befalls the main character as punishment, in this case it is not so, because Heracles never offends the gods in the first part. ${ }^{49}$ What escapes Mikalson's attention, however, is that both Heracles' family and the chorus keep speaking about him as better than Zeus, and Heracles himself does not hesitate to accuse Zeus and Hera in the last part of the tragedy (1263 et seq., 1303 et seq.). ${ }^{50}$

Complementary to such a perception of Heracles, which I'm not afraid to call a little idealised, is the way the figures of gods in the tragedy are interpreted by scholars. Kamerbeek who refrains himself from unilateral view of Heracles, at the same time claims that the fundamental thesis of the tragedy is the existence of bad, irrational forces in the universe, which are responsible for the main hero's misfortune, although anthropomorphisation of these forces in the tragedy is supposedly only a conventional technique of Euripides. ${ }^{51}$ Also Chalk does not hesitate to deem the gods as actually acting, totally bad persons/forces. It's

${ }^{46} \mathrm{~K}$. Hartigan (1987, 127-133) writes as follows: "In an effort to see a continuity in what seemed to be a discontinuous play, Wilamowitz suggested that a megalomaniac tendency was visible in Heracles' first appearance; his theory influenced earlier scholars but no one more recent than Grube (Drama, pp. 252-3), finds it true today."

47 "His madness is beyond his control, yet it acts through his virtue - his strength - to achieve his ruin. Thus, maddened, he takes his bow and sets out on another athlos." (Hartigan 1987, 128).

48 "Heracles may have been god-like, but he is not like god: the divinities kill and have no concern, but Heracles realizes his act and takes responsibility for it." (Hartigan 1987, 128).

49 "In all other regards Heracles is exceptional, even exemplary, in his piety" (Mikalson 1986, 96).

${ }^{50}$ Mikalson reaches for philosophical and theological explanations to justify some utterances of Heracles, and convinces us that Heracles speaks in them in the name of Euripides himself (Mikalson 1986, 89-98).

51 "What follows implies the repudiation of the very existence of the traditional anthropomorphic gods as gods but not of the evil powers responsible for Heracles' unhappy fate, 
them who, judging by Chalk's description, are practically insane and irrational, representing something he calls "Cosmic Madness", and are totally responsible for the madness that befalls the main character. On the other hand, Chalk protects Heracles from defaming him by Willamowitz and his interpretation followers, who attempt to ascribe bad intentions to Heracles. ${ }^{52}$

Over twenty years later, a similar picture of the gods can be found in a short study of Lefkowitz, devoted to the relationship of people to the gods in Euripidean tragedies, where she notices that the author many times sketches a picture of indifferent gods who do not embrace human moral standards (although these gods appear to be perhaps "human" rather than "less than human"). In addition, Heracles is considered to be a tragedy in which the gods are presented as forces unambiguously and exclusively ominous. ${ }^{53}$ This matter, however, is not unambiguous, as Lesky in the face of difficulties caused by the interpretation of the image of the gods in Heracles only states that "the role of the gods in Euripides raises many doubts; in Mad Heracles we get lost totally in this respect." 54

Accordingly, one group of scholars appears to represent an approach which to great extent is consistent with the way things are seen by the characters of the tragedy. This type of identification with the characters can be seen in the attempts to "save" and "protect" Heracles from the "charges" of Willamowitz and the like. For instance, according to Chalk, it's Euripides, as the author, who protects Heracles from any justification of political infanticide (which he allows Amphitryon twice) to save in this way his goodness from being tainted with evil. What's more, Chalk refers here to Heracles' personal "impression" of goodness. ${ }^{55}$

Many other scholars examining this tragedy have gotten a different "impression" perceiving in the figure of Heracles both a portent of madness and less noble features. Certainly, this is the case with Willamowitz and the early authors, ${ }^{56}$ but not only with them. Silk, as opposed to Chalk or Hartigan,

and such a repudiation may correctly be considered to be the final conclusion to be drawn from the presentation of Heracles' fate in the preceding tragedy." (Kamerbeek 1966, 9).

${ }^{52}$ Chalk 1962, 16-17. He writes: "Wilamowitz' picture of a megalomaniac brutalised by bloodshed is a caricature: but though Herakles is noble, bloodshed is brutal, the consequence of Cosmic Madness."

53 "Whatever these or other well-meaning mortals would like them to be, ,the powers which govern the world and man's destiny are unpredictable, implacable (though we must try to placate them), more often hostile than favourable, extremely rough in their justice, and [in the Heracles] downright malignant.'” (Lefkowitz quotes Stinton here, p. 82).

${ }^{54}$ Lesky 2006, 436.

55 "With Herakles himself Euripides is careful not to compromise our impression of his goodness by saying definitely that he would kill children when sane" (Chalk 1962, 17).

${ }^{56}$ Sheppard considers Heracles' idealisation unsettling (Sheppard 1916, 76-78), likewise later - Parry: "For the chorus elevate their hero to so dangerous a height that his fall becomes almost 
does not see in Heracles an explicitly good figure, but considers him - which is meaningful - to be an ambivalent figure. This author, similar to Barlow, seems to be sensitive to symptoms of bizarreness and discrepancy in the entire tragedy, and doesn't attempt to eliminate them like the scholars mentioned above. ${ }^{57}$ Heracles alone is seen by Silk as a figure holding contradictions - (1) unrealistic goodness and power coupled with terrifying destructiveness, as well as (1) divine and (2) human features. To explain this observation, Silk uses an anthropomorphic conception of Mary Douglas, which tells about creatures in between different worlds, not fully belonging to any of them, and thereby considered as dangerous in culture. ${ }^{58}$ The tragedy itself he describes as Heracles' passage from divinity to humanity.

Other scholars who observe evil in Heracles are: Hamilton, who demonstrates convergence of motifs among different images of Heracles in the tragedy, ${ }^{59}$ and - to some extent - Willink. ${ }^{60}$ Much more determined in this respect is Padilla, who sees Heracles as a saviour, hiding in himself a power destructive for his home. As a character, he oscillates between being god and human, recluse and friend, with an undetermined identity. ${ }^{61}$ Fitzgerald, in turn, in an intriguing way stands at the opposite end against Chalk and Hartigan in that he not so much sees any discrepancy in Heracles as outright declares that he is a rather negative character. While the above mentioned scholars "protect" the main character from accusations, Fitzgerald claims that they want to absolve him from his sins. According to this scholar, Heracles' identity is based on his delight taken in destroying and killing, in which he resembles Lycus, and his madness is an

inevitable." (Parry 1965, 364). Earlier Murray (1946, 106-126) claims that Euripides deliberately removes from the figure of Heracles the less noble or simply negative features, thus transforming him into a character more adequate for the epoch in which he lives. This is also noted by Silk (1985,

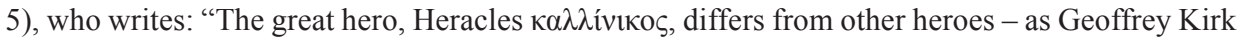
points out - in 'his brutality, his capacity for dishonesty and his voracious appetites'." Silk quotes here Kirk 1970, 177. He also makes reference to a list of Heracles' negative features in Galinsky (1972, 81-100).

57 "In the H.F. we have, in the first place, the bizarre rhythm of the play." Silk points out many ambiguities in the tragedy, for instance - why Hera sends madness on to Heracles. He also remarks that the authors generally avoid speaking of something that seems meaningful to him, i.e. that Heracles "is curiously unconvincing as a represented character." According to him, the scholars indicate this problem not through "eager discussions", but through their "reluctance to raise the question at all” (Silk 1985, 2-3).

58 "Heracles lies on the margins between human and divine; he occupies the no-man's-land that is also no-god's-land; he is a marginal, transitional or, better, interstitial figure." (Silk 1985, 6).

${ }^{59}$ Hamilton 1985, 22-23.

${ }^{60}$ Willink 1988, 88.

61 "As is often true in his mythical portrayals, the illustrious savior-hero is, at heart, an itinerant and a disruptive force to the oikos (cf. his roles in Alcestis and Trachiniae)" and "As such, the play leaves Heracles with an oddly ill-defined and unsettled identity, one that oscillates unstably between god and mortal, loner and philos." (Padilla 1992, 12). 
expression of what is "innate in his self" and a "logic of his own values." In the end he proves to be a coward. ${ }^{62}$

Even such a cursory review of interpretations of Heracles and the gods testifies to the existence of the processes which I have attempted to demonstrate in the tragedy itself. The image of both Heracles and the gods is subject to splitting, which means that extremely good or evil features are attributed to them with concurrent denial of the other part of the image. Divergent reactions of the scholars appear to reflect (in their unconscious) the psychotic composition of the tragedy, in which splitting, idealisation and denial dominate. ${ }^{63}$ Thus, there are two possibilities - either Heracles is totally good and innocent, and then the aggression contained in him is projected onto the gods, who become hostile and irrational persecutors, or Heracles is aggressive and mad, and what the gods are doing is somehow connected with what he is doing. Looking with detachment on this image points precisely to the main subject of Heracles, which is protection from psychotic fears through projection of aggression and envy onto external objects. When this protection breaks down, evil attack of these objects makes the main character go insane.

From the perspective of such a psychoanalytic interpretation, each of the extreme and diverse opinions of the scholars contains some part of the truth, depending on which aspect a scholar was sensitive to. However, this is not a question of a superficial statement "everybody is right", as with consistent application of psychoanalytic methods one has to arrive at certain conclusions in the issue of e.g. continuity of the psychotic process, and where to ultimately locate the destructive forces present in the tragedy.

It seems that the key issue is symbolic treatment of the world of the gods and the world of people. The world of the gods denotes what's internal, i.e. the sphere of primitive fantasies subject to violence, while the human world denotes what's external and real, i.e. the sphere where omnipotent control of the object is impossible. ${ }^{64}$ Other symbols related to this dichotomy include, on the one hand, dream, apparition, hallucination, night, and on the other hand, reality, logic, earth illuminated with sun. Silk rightly believes that Heracles lives on the border of these two worlds while belonging to neither of them. This means that in the first part of the tragedy he is neither fully detached from reality (except for the episode of madness), nor fully in contact with reality. Both the forces which

${ }^{62}$ Fitzgerald 1991, 91-95.

${ }^{63}$ Lesky $(2006,437)$ explains drastic discrepancies in the image of the gods, and the incoherence in the form of the tragedy by means of a conception of only two parts of the tragedy, but also one of its two concurrent dimensions, where one is a drama about a man who saved his family, and then murdered it, and the other - a mythological tragedy about a jealous goddess's hatred. In the entire play, he notices "gaps, tensions and cracks".

${ }^{64}$ Continual distortions of the gods' images impede interpretation of their role in the drama (see Lesky 2006, 436). 
attract him towards the world of the gods (in the direction of psychosis), and the forces pushing him towards reality (in the direction of sanity, or in other words, the depressive position, in Klein's terminology) are present in him. The tragedy as a whole, as Silk rightly argues, is a way from divinity to humanity ${ }^{65}$ that is one could supplement it - from fantasy to reality, and from psychosis to greater sanity.

If we follow this interpretative path, we must also admit that the figures of gods symbolise the objects, ergo, the forces residing inside the psyche (of Heracles, or rather - the analytic third of the drama), and not outside, in the "real world." Such an understanding of the world of the gods is not alien to the tradition of scholarly research in Euripides. Jacqueline de Romilly perceives two great topics of Euripidean tragedies: irrational passions consuming the man, and the gods' playthings reigning over human fate. ${ }^{66}$ In some plays (like Medea), the gods are deprived of their influence on human life, while in others the gods play with the man as a puppet. What's striking here is a similarity between these two spheres: psychic forces and the world of the gods. Romilly is sceptical about the psychoanalytic interpretations of the tragedy, ${ }^{67}$ so she doesn't associate them. Nevertheless, at the end of discussing Euripides' output, she states that "the gods we see in action, if they are not just symbols of human feelings, reiterate (in magnification) human passions." ${ }^{68}$

This view about the conflict between mind and passions has been recently referred to by Czerwińska, who points out Euripides' psychological approach in his dramas, particularly the motifs of love and death. In her opinion, the conditions of human actions reside in the psyche and experiences, and not in any external events, however, she does not make reference to any interpretations of divine characters in the tragedies. ${ }^{69}$ Elsewhere, Czerwińska states that "the gods sometimes appear in Euripides as a personification of internalised forces of the human soul, which condition the man's behaviour, thereby influencing the man's fate. Hera, Lyssa and Iris turn out to be personifications of the emotional element in the man, which reaches an intensity of madness. ${ }^{70}$

Even more emphatically in favour of such a symbolic understanding of the gods is Ferguson. He is confident that the gods, at least at a certain level of meaning, represent internal forces acting in the human psyche, and Euripides'

${ }^{65}$ Silk $1985,12$.

${ }^{66}$ de Romilly 1994, 116-140.

${ }^{67}$ For two reasons - the first being simply a disbelief in the influence of the unconscious on autonomous artistic intentions of the authors, and the other being a conviction about differences in the mentality between the people in Antiquity and people nowadays (de Romilly 1994, 146151).

${ }^{68}$ de Romilly 1994, 140.

${ }^{69}$ Czerwińska 2005, 783.

${ }^{70}$ Czerwińska 2005, 827. 
tragedy results from a situation in which these forces are too strong to be controlled. In writing about Heracles, Ferguson recognises Zeus as the symbol of affirmation of life or life-force, and Hera as the negation of life or power of death and destruction as opposed to Zeus. ${ }^{71}$ Silk suggests something similar with reference to Lyssa, who seems to be, like Iris, an independent goddess, but does not appear in the mythology - she personifies madness. The author suggests that the audience, bearing in mind the earlier murder of Linos, could assume that Lyssa simply means Heracles' own madness. Silk does not draw any further conclusions, although this contradicts his earlier statement: "there has been no sign of any insanity in Herakles." ${ }^{72}$ Winnington-Ingram and Knox also believe that the gods in Greek poetry symbolise uncontrollable forces of human life. ${ }^{73}$ Yoshitake agrees with such a possibility, but only sees in it an evidence of the gods' immorality, and not their potential "intrapsychic" status. ${ }^{74}$

Important are also observations of Dodds, who generally sympathised with using psychoanalytic tools to understand the Ancient culture, and particularly his analyses of what he calls "psychic intervention." In Dodds's approach, the gods and divine forces in the archaic culture symbolised (but this is a specific symbol) states of altered consciousness and being consumed by passions, which, however, did not release people from responsibility. From the Kleinian perspective, particularly interesting are Dodds's deliberations about wellknow Homeric metaphors of "putting something in the character's breast" by a goddess, or characteristic experiences of character, in which various parts of their personalities (of clearly somatic reference) are treated as autonomous to some extent. These are nearly typical descriptions of primitive introjection and projection, as well as of paranoid-schizoid fragmentation/splitting, which in a lesser intensity are visible in Heracles. Dodds's understanding is seemingly well suited for applications within the psychoanalytic interpretation of literature, as it concurrently admits some "realness" (from the perspective of the presented world) of divine forces, and psychological processes underlying such projections. ${ }^{75}$

Ferguson's and Silk's interpretations also harmonise with the psychoanalytic interpretation of the text. In the light of the assumptions made here, and the analytic conceptions used, the gods constitute internal objects of the space of the drama, which are then, through the fundamental projection mechanism, placed in the external world, and their images strongly split, idealised and omnipotently controlled. In a certain sense, therefore, for Heracles as the main character the gods are both real external beings (as Kitto writes, they exist "in a dramatic

\footnotetext{
${ }^{71}$ Ferguson 1969, 113.

${ }^{72}$ Silk 1985, 14, 16.

${ }^{73}$ Compare Winnington-Ingram 1960, 169-197; Easterling, Knox 1985, 322.

${ }^{74}$ Yoshitake 1994, 142.

${ }^{75}$ See Dodds 2001, 11-30.
} 
sense" of this $\operatorname{word}^{76}$ ), and a manifestation of his own psyche. What's important in the approach presented in this article is rather what happens with the images of the gods, as they are subject to intriguing operations - just as Heracles' image is - that can be explained using the notions of primitive defence mechanisms. None of the scholars explains - at least in a satisfactory and complete way - the reasons for these continual changes, and I believe that this can be done using the Kleinian theory of psychosis.

\section{BREAKDOWN OF DEFENCES AND DECOMPENSATION}

After clarifying the assumptions, let us look at the very moment of appearance of the psychotic episode as a result of a breakdown of the mechanisms of the paranoid-schizoid position. As early as at the beginning of the fourth epeisodion, still before Lyssa appears, the chorus is stricken with a strong fear of something undetermined (oĩov pó $\mu \alpha \alpha$ 817). Growing fear usually causes reaching for stronger psychotic mechanisms. From the level of the analytic third of the drama, the appearance of Lyssa and Iris can be considered as crystallisation of an unclear sense of threat in the form of specific persecutory objects. John Steiner writes: "This can be observed in patients of 'delusional mood', in whom extreme fear is accompanied by depersonalisation and a sense of indescribable terror; it seems that what brings them relief is the change of unidentified terror into a determined system of delusions. Some patients clearly calm down and feel better, when fears and feelings of being persecuted get limited to an area determined by a system of delusions controlled by the psychotic structure." ${ }^{\prime 7}$

Presence of the persecutory objects (Iris and Lyssa) also intensifies aggression of the subject, which manifests itself in Heracles' aggression. He defends himself against the (internal) threat from the objects through a sadistic attack. The tragic situation is that in this moment Heracles breaks any contacts with reality by attacking his own perception apparatus and his thinking, which is reflected in his experience of hallucinations and delusions. In this situation, Heracles' attack only in his fantasies is focused on the bad object (Eurystheus), while in reality he actually destroys the good objects. ${ }^{78}$ The bad objects are violently projected onto Heracles' real loved ones when he turns his back on reality.

\footnotetext{
${ }^{76}$ Kitto 1997, 229.

${ }^{77}$ Steiner 2010, 61.

${ }^{78}$ The delight taken by Heracles in destruction and killing as part of his identity is noticed by Fitzgerald (1991, 93), completely outside the psychoanalytic context. According to him: "The ,madness scene' expresses what is innate in that former self." Differently, Chalk $(1962,16)$, who states that the common feature of the bad Lycus and the good Heracles is violence only, but that this does not matter in view of the fact that their intentions vary totally. Thereby, Chalk omits the fact that Heracles feels satisfied with his aggression.
} 
This breaking of the contact with reality can only be explained in the context of what had happened earlier in the analytic third of the drama, and not only in Heracles himself. The main character's descent to Hades means a perilous immersion in the world of fantasies - parallel to this are the chorus songs portraying Heracles as a god. The splitting seemingly fulfils its function by separating good from evil and defending the psyche from excessive fear. It is visible, however, that the omnipotent idealisation of Heracles and combating the bad objects is growing as the tragedy unfolds. Heracles appears on the stage and omnipotently annihilates (real) Lycus, and with him the entire evil. This attack, though, is a defensive reaction to fear of his children's death. The children symbolise here the innocent and vulnerable aspects of the self whose existence is endangered.

The tragedy's turning point is a moment when the fear of the children's death at the hands of Lycus reaches its climax. Heracles appears on the stage having returned from the world of his omnipotent fantasies (the labours and Hades), and realises that the defence which idealisation provides to the child's parts of the psyche (symbolised by his children and family) is insufficient against the

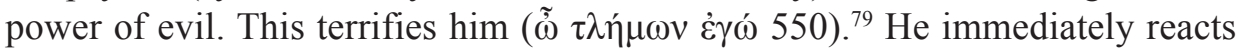
to the threat. Heracles states that his heroic deeds are nothing because his real duty is to protect his children (574-582). The atmosphere of fear returns at the end of the epeisodion (624-636). At first, the threat to his children's life pushes Heracles to act, when he sadistically murders Lycus.

The breakdown of defences is so put by John Steiner: "An individual can, despite everything, endure periods of extreme fear, if they manage to maintain normal splitting so that good experiences could survive. If, however, the splitting is broken down, the entire personality gets flooded with fear. This may cause an unbearable condition of catastrophic consequences. Splitting breakdown is particularly dangerous when the envy is intensive, as then destructive attacks can be directed to the good object so that the destruction cannot be split entirely." ${ }^{80}$

A portent of splitting breakdown can be observed in the chorus song that follows the return of Heracles, and which was analysed earlier. The chorus is

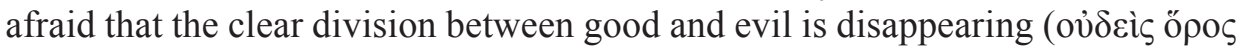

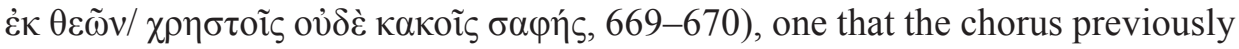
wanted to restore omnipotently by means of the fantasy of the second youth for the virtuous. In addition, there is another sign of breakdown, and that is envy. Here, envy manifests itself only subtly, because the chorus indirectly accuses the gods that they fail to divide good from evil, and keep good for themselves. Another symptom of envy is a further part of the song, where the chorus states that it will draw a dividing line by itself by virtue of the power of its song,

\footnotetext{
${ }^{79}$ Kitto $(1997,226)$ emphasises a mood of danger and awe dominant at that moment.

${ }^{80}$ Steiner 2010, 61.
} 
without any need of the gods, and finally, it equates Heracles with Apollo, which means robbing this god of his power and status.

By this moment the envy is growing, but it is also subject to denial. That's probably the way one should understand the third stasimon, in which the chorus suddenly restores the gods' original status, praises the marital bed that produced Heracles (798-804), ensures that it believes in Heracles' divine origin from Zeus, and thanks the gods for the fact that they like justice (813-814). Such an idealisation which follows directly after devaluation can be considered as defence against a growing power of envy (it was Heracles who saved the family, the gods did nothing). This defence, however, breaks down under pressure of the force of aggression and fear, when Iris and Lyssa appear on the stage.

In the scene that unfolds now, the envious projective identification is visible, too. Iris emphasises the effects of human envy (that of Amphitryon, Megara and the chorus) by saying that if Heracles went unpunished, the gods would be nothing in relation to the greatness of humans $(\theta \varepsilon \circ i \grave{\mu} \mu \grave{v} v$ ov̉ $\delta \alpha \mu$ ov/ $\tau \grave{\alpha} \theta v \eta \tau \alpha \grave{~} \delta$ ' $\left.\varepsilon_{\sigma} \sigma \tau \alpha \iota \mu \gamma \gamma \alpha \dot{\lambda} \alpha, 842-843\right)$. Iris is also guided by an envy which results from human envy. In the projective identification, the envy is placed in the object so that the object appears to be jealous of the self's goodness by raising fear of revenge. The gods feel so degraded by the humans that in their fantasies they try to take revenge, and take away the appropriated good. In the beginning, Lyssa surprisingly identifies herself with Heracles - she stresses his merits, the fact that he removed evil from the world and restored the gods' honour by his intention to save it from Hera's attack. ${ }^{81}$ However, after a while - which seems quite strange, and is not commented on by the scholars - she not only admits coldly that she must do what she is told to, but also her image of Heracles gets changed dramatically.

Lyssa's utterance reveals a sadistic satisfaction with a possibility of destroying the good achieved by the main character (861-873). If Lyssa really perceives virtue in Heracles, and even is grateful to him in a sense (since mentioning his restoring the gods' honour is another thing), then she should carry out her duty at least with a certain degree of reluctance, and not joy. What's present here is a strong parallel to Heracles, who also seems good in the beginning, and then bad, but the reader is encouraged to justify his violence with an external compulsion. Therefore, the fundamental dynamics consist in that the gods' aggression towards Heracles is closely related to Heracles' aggression towards Lycus - in a way, it's a response to it. ${ }^{82}$

\footnotetext{
${ }^{81}$ According to Lesky $(2006,431)$ : “Euripides couldn't have demonstrated the meanness of this action more effectively than through Lyssa's opposition."

${ }^{82}$ This is noticed by Padilla $(1992,5)$ in a similar use of $\delta$ ík $\eta$ in the description of the murder of Lycus (740), and the retribution for it by the gods (841-842). "Other verbal parallels reinforce this comparison, as does the fact that the two retributive actions are completed in the same location (the interior of the domos)." . He demonstrates that the motif of "Gorgon eyes", which at first was
} 
In this scene, Lyssa (object) is filled with envy at Heracles, but defends herself from it by admiring him. However, when she obtains "permission from above" to destroy the good being subject to envy, her defensive idealisation disappears and an underlying satisfaction coming from robbery and destruction is revealed. Still, Lyssa is, in a sense, Heracles' unconscious fantasy, and her envy at him is his envy at her. It's as if split parts of Heracles found themselves through projective identification in Lyssa and attacked him reflexively, destroying his defensive structure and provoking an attack on dependent parts of the self. Lyssa's admiration corresponds with the omnipotently idealised image of Heracles of the first part, her sadistic satisfaction with his sadism, her envy with his envy, and even blaming Hera is in common here.

The mechanisms protecting from fear break down, and Heracles becomes overtly psychotic. In the Messenger's description, both hallucination, and delusions can be seen - Heracles does not know where he is, he travels, chases and kills, he thinks, Eurystheus and his children believing that his own family is the internal objects he hates. The attack on Eurystheus is also a defence against a destroying attack that Heracles fears, and which is symbolised by the threat to his children's and wife's lives.

It's also worthwhile to note a process of multiplying bad objects. Previously, it was only Lycus, and now there are four of them: Hera (who does not appear on

an attribute of Heracles (in his children), now returns as an attribute of Heracles overwhelmed by Lyssa - the projected aggression destroys the self. A similar function performs Heracles' club, which at first is an attribute of his saving labours, and then smashes his son's head (Padilla 1992, 7-8 and 12). Similarities are also perceived by Fitzgerald (1991, 93) and Willink $(1988,88)$ writing of a double meaning of $\pi$ óvos. At first, these are omnipotent heroic deeds, and subsequently, passive suffering under the impact of the attack of the gods - the relation between the aggression of the self and being persecuted is visible here. Hamilton $(1985,22-23)$ also demonstrates how the same expressions appear in Amphitryon's description of Heracles' heroism, the description of Lyssa, and the Messenger's account of Heracles' madness. For instance, the goddesses unite in the fight against Heracles (825), just as he had united with them in the fight against the Giants (180). Previously, Heracles was lined up with Zeus armed with a thunderbolt (177), and now he takes a blow worse than a thunderbolt (862). Previously, Heracles celebrated the victory in a comos (180), and now Lyssa playing to him on an aulos of fear will force him to a dance of destruction (871). Silk $(1985,17)$ considers the dialogue between the goddesses as "by any standard, extraordinary." He points out to Lyssa's "identification" with Heracles, when she defends him, and a general "intimate relationship" between them. Silk's psychological intuition does not fail him, when he writes that a metaphor of Heracles' fighting with his own madness is visible here, only that at the same time this is a process of intensification of this madness through projection. "He is the killer and she is the killer, because she is both independent of him and an aspect of him. The staging makes her external; the words tend to suggest her internality" . Kamerbeek demonstrates Euripides' use of tragic irony that combines what can be called a psychosomatic condition with overtly psychotic condition. For instance, Megara is afraid that her children will be killed by Lycus, and in the end they get killed by Heracles, who is a "negative" Lykos. Amphitryon (Kamerbeek 1966, 158-203) defends from Lycus the value of Heracles' "bow and arrows", which later on will turn out to be an instrument of murder, etc. (Kamerbeek 1966, 6). 
the stage and is only mentioned from time to time), Iris (who wants to enviously destroy Heracles), Lyssa (most associated with Heracles' psyche), and Eurystheus (present in the hallucinations, directly responsible for the threat to the lives of Heracles' family). It seems that this configuration resembles an intrapsychic "pathological organisation" first described by Rosenfeld, and currently this conception has been widely developed and applied by contemporary Kleinists, such as John Steiner. According to this idea, the psyche contains introjected objects which organise into a kind of "gang" or "mafia." The innocent and dependent part of the self is seduced and imprisoned by that gang, and relations with it are strengthened by the projective identification, because the bad parts of the self are placed in these objects and give them strength, and the dependent self is controlled, tortured or killed by such a gang, and concurrently, this organisation convinces the self that it is the only entity which can protect it from other, external persecutors. ${ }^{83}$

In the pathological organisation present in Heracles Hera dominates, who only appears in the characters' utterances, and still, she is Heracles' main opponent. She is a textbook example of inexhaustible, ideal breast at which the baby feels pathological envy. With respect to the myth, we can see how the divine, abundant breast which Heracles tries to insidiously suck out, not only denies him its inexhaustible riches, but begins to actively persecute him in retaliation. At its service is Eurystheus, who substitutes for her to persecute him, thus endangering the existence of his family, as well as Iris and Lyssa, who rob him of everything at the moment of his greatest success. The object convinces Heracles, who no longer has contact with reality, that he must kill Eurystheus and his children (innocent and dependent self) for his own protection, but as a result they provide themselves a cruel entertainment by watching how Heracles, convinced that he is defending himself, destroys himself.

Therefore, what I suggest from this perspective is to recognise the existence of psychological continuity within the analytic third of the drama between the psychotic processes of the first part and the breakdown described in the second part, and I agree with some scholars who emphasise that it is hard (but not impossible) to discover this continuity solely in Heracles' conscious thoughts, feelings and behaviour on the stage. ${ }^{84}$

\footnotetext{
${ }^{83}$ Steiner 2010, 75-94.

${ }^{84}$ Silk $(1985,17)$ writes: "There is no psychological continuity between Heracles now and before: there is, rather, a metaphysical continuity between Heracles and the divine realm of which madness (as Greek ideology tended to affirm) was one part." This "metaphysical continuity" is nothing other than a continuity of unconscious psychic processes, assuming that the gods may constitute a symbolic projection of unconscious fantasies.
} 


\section{ENDING: HERACLES BETWEEN FANTASY AND REALITY}

Most of the previously quoted scholars draw attention to the progressive "realism" of the tragedy, particularly to a clear difference between Heracles in parts I and II, and Heracles in part III. In the psychoanalytic perspective, the issue here is a passage from the paranoid-schizoid position to the depressive position, with surprisingly violent decompensation in the centre of this process. The tragedy talks about a madness, but also about a road to reality and sanity. In this article, I have concentrated on the presence of psychotic phenomena in Heracles in order to demonstrate that Heracles' madness mentioned in the title is nothing accidental and unexpected in the course of the plot. However, while by that moment the tragedy is a case study of madness, the exodos is a case study of struggling for psychic health, working out the depressive position, whose effects are surprisingly successful. Overall, Heracles turns out to be less mad then it seems during the tragic murder of his loved ones. For a lack of space, however, a more sane and less mad aspect of Heracles and the tragedy about him have not appeared in this article, although it is present in the last part of the tragedy. ${ }^{85}$

With the approach applied here, it is sensible to adopt a final division of the tragedy not in three parts, but in two parts - the first one (by the end of the fourth stasimon), dominated by the paranoid-schizoid position with the decompensation episode at the end, and the other one (exodos), dominated by the depressive processes which in this presentation have been omitted, but which are worth analysing to obtain a more complete picture of this extraordinary tragedy. Let me conclude quoting one of the scholars: "The Heracles myth, on the contrary, is all contradiction itself, contradiction which the tragedians explore at some cost to the tragic norms and to our emotions." ${ }^{86}$

\section{BIBLIOGRAPHY}

\section{Primary sources}

Eurypides, Hercules, ed. K.H. Lee, BSB B.G. Teubner Verlagsgesellschaft, Leipzig 1988.

\section{Secondary sources}

Arrowsmith 1954: Arrowsmith, W. The Conversion of Heracles, Diss. Princeton, Princeton). Barlow 1982: Barlow, S. A. 1982. "Structure and Dramatic Realism in Euripides' Heracles." Greece \& Rome, $2^{\text {nd }}$ series, 29, no. 2:115-125.

Bion 2010: Bion, W.R. 2010. Uwaga i interpretacja, translated by D. Golec, Warszawa.

Burnett 1971: Burnett, A.P. 1971 ."The Madness of Heracles", in: Catastrophe Survived, 165. Oxford.

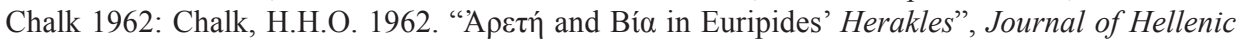

Studies 82:7-18.

\footnotetext{
${ }^{85}$ The relationship between the first and the second part of Heracles has been the focus of my article: Stróżyński 2013, 223-250.

${ }^{86}$ Silk 1985, 19.
} 
Conacher 1967: Conacher, D. J. 1967. Euripidean Drama, Toronto and London.

Czerwińska 2005: Czerwińska, J. 2005. “Eurypides i jego twórczość dramatyczna”, In: Literatura Grecji starożytnej, vol. I, H. Podbielski, I, H. 2005 (ed.). Lublin.

Dodds 2001: Dodds, E.R. 2002. Grecy i irracjonalność, translated by J. Partyka, Bydgoszcz.

Dybel 2009: Dybel, P. 2009. Okruchy psychoanalizy. Teoria Freuda między hermeneutyka $i$ poststrukturalizmem, Kraków.

Easterling and Knox 1985: Easterling, E. and Knox, B.M.W. 1985. (ed.), The Cambridge History of Classical Literature, Cambridge.

Ferguson 1969: Ferguson, J. 1969. "Tetralogies, Divine Paternity, and the Plays of 414", Transactions and Proceedings of the American Philological Association 100: 109-117.

Fitzgerald 1991: Fitzgerald, G. J. 1991. "The Euripidean Heracles: An Intellectual and a Coward?", Mnemosyne $4^{\text {th }}$ series 44: 85-95.

Galinsky 1972: Galinsky, G. K. 1972. The Herakles Theme, Oxford.

Hamilton 1985: Hamilton, R. 1985. "Slings and Arrows: The Debate with Lycus in the Heracles", Transactions of the American Philological Association 115: 19-25.

Harsh 1948: Harsh, P.W. 1948. A Handbook of Classical Drama, Stanford.

Hartigan 1987: Hartigan, K. 1987. "Euripdean Madness: Heracles and Orestes", Greece and Rome 34: $126-35$

Holland 1993: Holland, N.N. 1993. "Psychoanalysis and Literature - Past and Present", Contemporary Psychoanalysis 29 (1): 5-21

Holland 1998: Holland, N.N. 1998 "Reader-Response Criticism", International Journal of Psychoanalysis 79: 1203-1211.

Kamerbeek 1966: Kamerbeek, J.C. 1966. "The Unity and Meaning of Eurypides' Heracles, Mnemosyne $4^{\text {th }}$ series, 19: 1-16;

Kirk 1970: Kirk, G. S. 1970. Myth: Its Meanings and Functions in Ancient and Other Cultures, Cambridge.

Kitto 1997: Kitto, H.D.F. 1007. Tragedia grecka. Studium literackie, translated by J. Margański, Bydgoszcz.

Klein 2007a: Klein, M. 2007 Miłość, poczucie winy i reparacja. Pisma, vol. I, translated by A. Czownicka, H. Grzegołowska-Klarkowska, Gdańsk.

Klein 2007b: Klein, M. 2007. Zawiść i wdzięczność. Pisma, vol. III, translated by A. Czownicka, H. Grzegołowska-Klarkowska, Gdańsk.

Lesky 2006: Lesky, A. 2006. Tragedia grecka, transl. M.Weiner, Kraków.

Mikalson 1986: Mikalson, J. D. 1986. "Zeus the Father and Heracles the Son in Tragedy", Transactions of the American Philological Association 116: 89-98

Murray 1946: Murray, G. 1946. Heracles: Best of Men, [in:] Greek Studies, 112. Oxford.

Norwood, 1964: Norwood, G. 1964. Essays on Euripidean Drama, London-Toronto.

Ogden 1994: Ogden, T. 1994. "The Analytic Third: Working with Intersubjective Clinical Facts" International Journal of Psychoanalysis 75: 3-19.

Ogden 2010: Ogden, T. 2010. Ponowne odkrywanie psychoanalizy. Myślenie, śnienie, uczenie się i zapominanie, translated by L. Kalita, Warsaw.

Ogden 2011: Ogden, T. 2011. Sztuka psychoanalizy. Śnienie niewyśnionych snów i urwanych krzyków, translated by D. Golec and L. Kalita, Warsaw.

Padilla 1992: Padilla, M. 1992. "The Gorgonic Archer: Danger of Sight in Euripides' Heracles", Classical World 86: 1-12.

Parry 1965: Parry, H. 1965. “The Second Stasimon of Euripides' Heracles (637-700)", American Journal of Philology 86: 363-364.

de Romilly 1994: de Romilly, J. 1994. Tragedia grecka, translated by I. Sławińska, Warszawa.

Segal 2005: Segal, H. 2005 Wprowadzenie do teorii Melanie Klein, translated by Ł. Penderecki, Gdańsk. 
Segal 2006 (1957): Segal, H. 2006. "Uwagi o tworzeniu symboli” (1957), in: Teoria Melanie Klein w praktyce klinicznej, translated by D. Golec, G. Rutkowska, A. Czownicka, Gdańsk.

Sheppard 1916: Sheppard, J. T. 1916. 'The Formal Beauty of the "Hercules Furens", Classical Quarterly 10: 72-79.

Silk 1985: Silk, M. S. 1985. "Heracles and Greek Tragedy", Greece \& Rome, $2^{\text {nd }}$ series, vol. 32, No. 1: 1-22.

Steiner 2010: Steiner, J. 2010. Psychiczny azyl. Patologiczna organizacja osobowości u pacjentów psychotycznych, nerwicowych i borderline, translated by M. Żylicz, L. Kalita, M. Lipińska, Gdańsk.

Stróżyński 2013: Stróżyński, M. 2013. 'Love, Aggression, and Mourning in Euripides’ Heracles', Eos 100: 223-250.

Verrall 1905: Verrall, A.W. Four plays of Eurypides, Cambridge 1905

von Wilamowitz-Moellendorf 1895: von Wilamowitz-Moellendorf, U. 1895. Euripides' Herakles, Berlin.

Willink 1988: Willink, C.W. 1988. "Sleep after Labour in Euripides' Heracles", Classical Quarterly 38: 86-97.

Winnington-Ingram 1960: Winnington-Ingram, R.P. 1960. "Hippolytus: a study in causation", in: Euripide, Entretiens sur l'antiquité classique VI: 169-197.

Yoshitake 1994: Yoshitake, S. 1994. "Disgrace, Grief and Other Ills: Herakles' Rejection of Suicide", The Journal of Hellenic Studies 114: 135-153.

\section{PSYCHOTIC PHENOMENA IN EURYPIDES' HERACLES}

\section{Sum mary}

Euripides' Heracles has drawn the attention of numerous scholars since Willamowitz's excellent commentary on the play. The play has been seen as lacking unity, full of contradictions, incoherent, bizarre even. Later critics tried to show structural unity, especially by analysing recurrent motifs and ideas. The madness was explained by Willamowitz, Verrall, Pohlenz, Grube, and others with reference to Heracles' inner process, of a "megalomaniac" character. Such psychological interpretations of madness were widely questioned in the second half of the $20^{\text {th }}$ century, and Heracles himself provoked extreme reactions and opinions by scholars. In the article Heracles' madness is considered a central theme of the play, expressed both in the fragmented and split structure of it and in the contradictions and bizarre elements within the tragedy. I used Melanie Klein's (especially, the concepts of the paranoid-schizoid and depressive positions as well as of primitive defence mechanisms) and her followers' (especially, Segal's notes on symbol formation and Bion's theory of psychotic thinking) theory to show the essentially psychotic character of the play. The dramatis personae, in their behaviour and words manifest such psychotic mechanisms as splitting, denial, idealisation, projective identification, and omnipotent control, as well as primitive envy. The gods can be seen as projections of Heracles and other characters, as well as of the common unconscious space of the play ("the analytic third" of the tragedy, to use Thomas Ogden's concept). The climactic Heracles' madness is understood as a breakdown of psychotic defence mechanisms, cause by intense, yet split off, envy and by a powerful threat to dependent parts of the self, symbolised in Heracles' children and wife. The whole tragedy is a way from the world of fantasy, gods, underworld towards the more realist world of human beings and their relationships, which in Kleinianism can be conceptualised as a movement from the paranoid-schizoid position to the depressive one. 